\title{
THE CONCEPT OF DEVELOPMENT OF THE LEGISLATION AS THE WAY OF IMPROVEMENT OF THE REGULATORY FRAMEWORK OF THE STATE BORDER GUARD SERVICE OF UKRAINE
}

\section{Olha Basarab}

\section{INTRODUCTION}

New types of threats at the state border of Ukraine caused by constant attacks on our territory, spreads of terrorism and other illegal activities, require from the State Border Guard Service of Ukraine proper counteractions in order to ensure the security of the state border as an element of the national security of Ukraine. Obviously, the implementation of the functions by border-guards should be based on qualitative regulatory support. To date, the legal regulation of public relations in the sphere of activity of the State Border Guard Service of Ukraine is carried out by a number of normative acts, the legal norms of which require substantive analysis as they are in some way obsolete, contain conflicts, gaps and inaccuracies.

The problem of the effectiveness of regulatory framework of the border service is widely discussed by our scholars: Oleh Han'ba, Valentyn Z'olka, Yuriy Ivashkov, Mykola Kabachyns'kyy, Roman Lyashuk, Iryna Kushnir, Yuriy Kurylyuk, Nataliya Orlovs'ka, Serhiy Khalymon and others. Unfortunately, there are practically no systematic approaches in the scientific literature to determine the ways of further development and improvement of legislation of the State Border Guard Service of Ukraine activity.

The listed factors contribute to the formation and adopting the conceptual document with the set of main principles in the norm-making sphere on border protection.

The problem presented in the publication concerning the comprehensive study of the current state of the legislation of the State Border Guard Service of Ukraine as an independent normative complex in the system of national legislation and defining the concept of its development. 


\section{The notion and the structure of the legislation of the State Border Guard Service of Ukraine}

For today the conceptual basis of the legislation that regulates operational and service activity of the State Border Guard Service of Ukraine is in a process of formation. That is why in order to work out the concept of its development we have to understand the meaning of the notion - "legislation".

The problem of investigation of the legislation as the legal phenomenon is still considered actual both in Ukraine and abroad. In European Union countries with continental legal system it is also paid the great attention to it, especially in the context of correlation of national and European Union legislation ${ }^{1}$. As a rule the content of this notion is interpreted as a totality of laws issued and officially approved by parliament ${ }^{2}$.

In Ukrainian theory of law there are three approaches to "legislation":

broad - it is the system of the all normative and legal acts;

median (between broad and narrow meaning) - it is the system of the normative and legal acts of public authorities: parliament, president, government;

narrow - it is the system only of the parliamentary acts and treaties ratified by parliament.

Taking into consideration that operational and service activity of the State Border Guard Service of Ukraine is regulated by the great number of subordinate normative acts the broad approach is more acceptable for our scientific research.

The analysis of the nature of functions of the State Border Guard Service determined in legal acts let us make a conclusion that the subject of legal regulation of the mentioned legislation is social relations, connected with full-filling by border-guards law-enforcement, special, operational and combat activities in the social space that creates the separate sphere of legal regulation.

Law-enforcement activity includes: control through the state border and to the temporarily occupied territory and from it persons, vehicles, cargoes, as well as detection and termination of cases of illegal

\footnotetext{
1 Alexander Turk. (2006) The Concept of Legislation in European Community Law: A Comparative Perspective. New York: Kluwer Law International B.V.p.10.

2 Cambridge Dictionary Cambridge: Cambridge University Press University Printing House. Retrieved from: https://dictionary.cambridge.org/dictionary/english/legislation (accessed 16 October 2019).
} 
movement of them; conducting information-analytical and operationalsearch activities; combating organized criminality and illegal migration at the state border of Ukraine and within controlled border areas; combating terrorism; coordination of activities of bodies carrying out different types of control at the state border.

A characteristic feature of the law-enforcement activity of the State Border Guard Service of Ukraine is that it is carried out in accordance with the current legislation of Ukraine and it is realized with the set of measures aimed at preventing and ending offenses at the state border of Ukraine.

In the context of combat actions in the east of our country and the involvement of separate border units first in the anti-terrorist operation and now in the operation of the joint forces the staff of the State Border Guard Service Ukraine together with law-enforcement functions performs operational and combat activities related to the protection of the territorial integrity of our country.

To date, the main military threats that border guards must counteract are: provocations of the enemy at the state border (administrative border, demarcation lines); the destructive activity of the enemy's sabotage and reconnaissance groups in the border area and the controlled border area; armed invasions of illegal armed formations or units of the armed forces into the territory of Ukraine.

Operational and combat activity of the State Border Guard Service Ukraine includes: conducting intelligence, information-analytical and operational-search activities on the state border of Ukraine; combating the activities of illegal militarized or armed forces (groups) on the state border of Ukraine; coordination the activities of military formations and law enforcement agencies related to the protection of the state border of Ukraine.

Separate form of State Border Guard Service function that cannot be attributed to the law-enforcement or operational and combat activities is special activity. It is connected mainly with participation of the border guards in protection of places of permanent and temporary stay of the President of Ukraine and other officials, as well as the protection of foreign diplomatic institutions of Ukraine.

Based on the results of the research of a number of approaches related to understanding the content of legislation and functions of border guards the essence of the legislation regulating activity of the State Border Guard Service of Ukraine is proposed to understand as the system of current material and procedural legal acts of Ukraine and the norms of 
international law, which determine the performance of the State Border Guard Service special functions in law enforcement, special, operational and combat forms of activity in order to ensure the inviolability of the state border and the protection of the sovereign rights of Ukraine in its exclusive (maritime) economic zone.

The particular importance of finding out conceptual approaches for developing the legislation of the State Border Guard Service stipulates the need to analyze the structure of its system. Normally, the structure of legislation is organization of legal acts, which is expressed in their coherence, differentiation and integration into structural units. The structure of the legislation definitely ensures its integrity.

Mainly the structure of legislation is studied in three dimensions:

hierarchical (vertical) - analyzing the legal force of acts;

legal branch principle (horizontal) - by division of normative legal acts on the subject of legal regulation;

state-organizational (federal) - dividing legal acts by territorial significance.

Each of these structures has its own characteristics and allows to analyze the legislation, applying different approaches of studding its nature.

Taking into consideration the theme and aim of our research it would be better to study the hierarchical structure of legal framework of the Border Guard Service. For, as Victoria Sukhodubova rightly points out that practical importance of the hierarchical (vertical) structure of legislation is that it embodies exclusively hierarchical relations in the system (subordination, integrity and conformity of acts), it also makes a significant impact on ensuring internal coherence and legal unity of the system $^{3}$. And in addition, the study of conceptual approaches to the development of legislation is impossible without a detailed analysis of the entire structure of regulatory acts, beginning with the law and ending with local act.

The hierarchical structure of the legislation of the State Border Guard Service of Ukraine depends on the legal force of normative acts caused by position of agency issued it.

Taking into account scientific positions regarding the classification of normative acts by their legal force, let us define the hierarchical (vertical)

${ }^{3}$ Sukhodubova I. V. (2015) Ekonomichna teorija ta pravo [Economic theory and Law]. Law and security, vol. 1, no. 20, p. 272-273. 
structure of the legislation in the sphere of the State Border Guard Service activity: the Constitution of Ukraine; the laws of Ukraine; decrees and orders of the President of Ukraine; resolutions of the Cabinet of Ministers of Ukraine; directives and orders of the Ministry of Internal Affairs of Ukraine and the Administration of the State Border Guard Service of Ukraine; orders of normative character of regional departments and divisions of the State Border Guard Service of Ukraine.

Considering that tasks at the state border are related to the foreign policy and foreign economic activity of our country, which implies international cooperation on border issues, norms of international law can also be considered as an element of the legislation of the State Border Guard Service of Ukraine.

Under the Article 9 of the Constitution of Ukraine international treaties, ratified by the Verkhovna Rada of Ukraine are considered as a part of the national legislation of Ukraine ${ }^{4}$. In the border guard sphere international treaties can be signed on demarcation, friendship, cooperation, mutual assistance in security and boundary aspects.

International treaties of Ukraine may be concluded by the President of Ukraine, or on his behalf; by the Cabinet of Ministers of Ukraine, or on its behalf; by ministries, other central executive bodies, as well as state bodies on behalf of ministries, other central executive bodies, state bodies.

The laws of Ukraine form the starting point in the legal regulation of public relations on the state border. They have the highest legal force in relation to other normative acts and create the legal frame of the Border Guard Service.

Among the characteristic features that distinguish laws from other normative acts are the following:

they can be issued by specially authorized subjects - parliament or people through a referendum;

regulate the most important social relations and establish their baselines;

have a higher legal force;

they can be adopted in accordance with a specific legislative procedure.

${ }^{4}$ Konstytucija Ukrajiny vid 28 chervnja 1996 roku No. 254k/96-VR. [Constitution of Ukraine of June 281996 No. 254k / 96-VR.]. Retrieved from: http://zakon3.rada.gov.ua/ laws/show/254\%D0\%BA/96-0\%B2\%D1\%80 (accessed 16 October 2019). 
On the top of the structure of legislation there is the Constitution of Ukraine of 28 June 1996. Constitutional norms create the legal basis for regulating the activity on the state border. As a rule general norms of Constitution are implemented in ordinary laws. For example, Article 17 of the Basic Law determines that military formations and law enforcement agencies are responsible for the security of the country and protection of the state border of Ukraine. The detailed explanation of this statement is in the ordinary Law "On the State Border Guard Service of Ukraine" of 4 November 1991 where it is written that the protection of the state border is an integral part of the national security system, coordination of activities of military formations and law enforcement agencies on the state border protection is carried out by the State Border Guard Service of Ukraine 5 .

Taking into consideration scientific positions on the classification of ordinary laws we have classified ordinary laws in the sphere of the Border Guard Service activity into general and special laws. General laws have general content and can be applied to all subjects of law. For example: "On the Defense of Ukraine" of 6 December 1991, "On the State Secret" of 21 January 1994, "On Legal Regime of Emergency" of 16 March 2000, "On Protection of Personal Data" of 1 June 2010, "On the Legal Regime of Martial Law" of 12 May 2015, "On the Features of State Policy for Ensuring State Sovereignty of Ukraine in Temporarily Occupied Territories in Donetsk and Luhansk Regions" from 18 January 2018,"On the National Security of Ukraine" from 21 June 2018 etc. Otherwise special laws refer to particular activity of the border guards detailing the performance of their functions. For example: "On the State Border Guard Service of Ukraine" of 3 April 2003, "On the State Border of Ukraine" of 4 November 1991, "On the Border Control" of 5 November 2009 etc.

Codified normative acts, that are presented by the Codes: Criminal Code of 5 April 2001, Customs Code of 13 March 2012, Code of Ukraine on Administrative Offenses of 7 December 1984 etc., play also an important role in regulating public relations in the sphere of activity of the State Border Guard Service of Ukraine and have the same legal force as ordinary laws.

${ }^{5}$ Pro Derzhavnu prykordonnu sluzhbu Ukrajiny : Zakon Ukrajiny vid 3 kvitnja 2003 roku No. 661-IV [On the State Border Service of Ukraine: Law of Ukraine of 3 April 2003 No. 661-IV]. Retrieved from: http://zakon2.rada.gov.ua/laws/show/661-15/page (accessed 31 October 2019). 
Subordinate legal acts form the largest group of acts regulating the activities of the State Border Guard Service of Ukraine, they detail and specify the norms of acts of higher legal force, carry out a more detailed legal norms of social relations in the field of activity at the state border. The hierarchy of subordinate legal acts depends on the body that issue an act.

The President of Ukraine signs international treaties of Ukraine, issues decrees and orders related to appointment of the Chairman of the State Border Guard Service of Ukraine; use of the Armed Forces and border units in the armed aggression against Ukraine; total or partial mobilization; declaration of martial law in Ukraine or in some of its localities; declaration of a state of emergency in Ukraine or in certain localities; declaration certain areas of Ukraine as zones of emergency ecological situation conducting negotiations etc. For example: "On the National Security Strategy of Ukraine" of 6 May 2015, "On the new version of the Military Doctrine of Ukraine" of 2 September 2015, "On the Concept of Development of the Security and Defense Sector of Ukraine" of 4 March 2016 etc.

Resolutions of the Cabinet of Ministers of Ukraine play an important role in regulating the activity of the State Border Guard Service of Ukraine because due to their legal nature they concretely detail general norms of the higher legal acts. In other words they explain how and in what way the tasks of the higher state authorities should be implemented. As a rule, the government issues resolutions related to the contractual legal border clearance, maintaining legal relations on it, as well as carrying out activities to ensure the implementation of state policy in the field of border protection. For example: "On the Border Regime" No. 1147 of 27 July1998, "On Controlled Border Regions" No. 1199 of 03 September 1998, "On Approval of the Procedure of Entry into the Temporarily Occupied Territory of Ukraine and departure from it" No. 367 of 4 June 2015, "Issues of counteraction to illegal movement of goods across the state border of Ukraine" No. 371 of 8 June 2016 etc.

At the bottom of the hierarchical structure of legislation that regulates the Border Guard Service activity are the directives and orders of the Ministry of Internal Affairs of Ukraine and the Administration of the State Border Guard Service of Ukraine that despite the presence of a certain number of primary norms, contain derivative norms from acts of higher legal force. The main task of such acts is to give proper instructions for caring out norms of higher legal force acts. For example: "On Approval of the Instruction on the Border Guard Service of the State 
Border Service of Ukraine” No. 1261 of 19 October 2015, “On Approval of the Regulation on the Border Commandant's Rapid Response of the State Border Guard Service of Ukraine" No. 190 of 21 March 2016, "On approval of the Regulation on the Border Service Division of the State Border Service of Ukraine” № 31115 April 2016.

Under the Order of Agency of the State Border Guard Service of Ukraine "On the List of Basic Guidance Documents" No. 63 of 16 March $2015^{6}$ orders of normative character can also be issued within their powers by heads of regional departments and divisions of the State Border Guard Service of Ukraine: "On the organization of operational and service activities", "On the organization of operational and search activities", "On the organization of counter-terrorism events", "On the organization of protection of the exclusive (maritime) economic zone of Ukraine, its territorial and inland waters", "On Engineering and Technical Support of State Border Protection and Environmental Security", "On the organization of rear support of the state border protection" etc.

Thus, we can conclude that nowadays the State Border Guard Service of Ukraine has required quantity of different legal force acts that constitute structured legal system in the separate sphere of regulation and form the firm regulatory framework for its functioning. But despite of this it does not matter often quality.

\section{Theoretical approaches to the creation of the Concept of development of the legislation of the State Border Guard Service of Ukraine}

A comprehensive research of scientific works on this topic, analysis of the legislation regulating the activity of Border Guard Service, and the results of a survey of border guards allowed us to highlight the following regulatory deficiency:

some of normative acts are obsolete, contain conflicts and inaccuracies;

insufficient promptness of amendments to legal documents in line with changes in the situation at the state border;

${ }^{6}$ Pro perelik osnovnykh kerivnykh dokumentiv : Nakaz Administraciji Derzhavnoji prykordonnoji sluzhby Ukrajiny vid 16 bereznja 2015 roku No. 63 [On the List of Basic Guidance Documents: Order of the Agency of the State Border Guard Service of Ukraine dated March 16, 2015 No. 63]. Retrieved from: https://dpsu.gov.ua/ (accessed 31 October 2019). 
gaps in legal regulations of the State Border Guard Service of Ukraine activity;

the declarative nature of some legal acts.

In percentage ratio this problem gave the following results (Fig. 1).

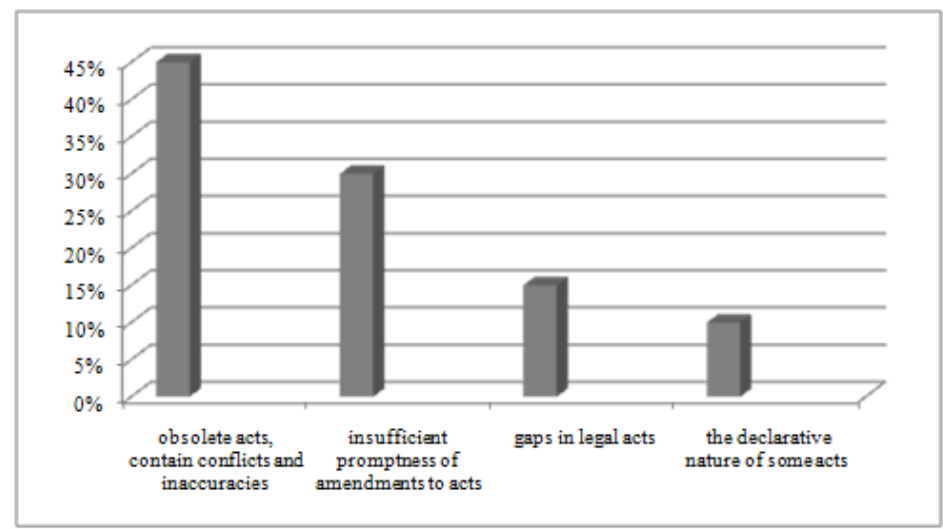

\section{Fig. 1. The percentage ratio of current regulatory deficiency of the State Border Guard Service of Ukraine}

In view of the foregoing the problem of the effectiveness of legislation in the sphere of the State Border Guard Service activity demands systematic research and working out approaches to its developing in order to improve it. Analysis of scientific positions on ways of improving the regulatory framework of the State Border Guard Service of Ukraine leads us to conclusion that at the end of the process of improving legislation must be effective legislation.

The famous Ukrainian layer Petro Rabinovych points out that legal effectiveness comes when the content of the purpose of the law is precisely legal consequences, such as changes in the legal status of a certain group of persons, or in the specific rights and obligations of personified entities. In all other cases it is possible to speak about the social effectiveness of the law ${ }^{7}$.

Natalia Onishhenko proposes to consider the problem of the effectiveness of legislation taking into account the following factors: the

\footnotetext{
${ }^{7}$ Rabinovych P. M. (2007) Osnovy zaghaljnoji teoriji prava ta derzhavy [Fundamentals of the general theory of law and state]. Lviv: Kraj, p.192 (in Ukrainian)
} 
legislative process; the quality of the law; professionalism of normmakers; integration processes ${ }^{8}$.

Similar views are held in scientific work by Natalia Dubyna ${ }^{9}$. Pavlo Kindrat adds to such criteria of effectiveness of legislation as social efficiency of legislation and quality of legislation mentioned above the socially beneficial character of the result of the effect of the legal norm, which is expressed in material costs of human energy and time to achieve the goals ${ }^{10}$.

Summarizing the aforementioned scientific positions, it can be argued that the effectiveness of legislation is a very important feature, reflecting the ability of legal acts to solve social and legal problems, while ensuring the proper legal regulation of social relations in any spheres.

The existence of a large number of scientific approaches to formulating the effective legislation brought us to conclusion that the main requirements for its creating are quality and quantity of normative acts. Because a certain qualitative certainty of the subject always corresponds to not only quantitative certainty, but the necessary ${ }^{11}$. Therefore, in order to create the high quality legislation of the Border Guard Service, it is necessary to have a sufficient number of interconnected and mutually agreed upon content and form of legal acts that will complete the inclusive regulation of public relations at the state border.

The existing regulatory framework on border issues is represented by a large number of legal acts, among which $10 \%$ are laws of Ukraine, $5 \%$ - decrees of the President of Ukraine, $15 \%$ - resolutions and enactments of the Cabinet of Ministers of Ukraine, $30 \%$ - orders of the Ministry of Internal Affairs of Ukraine and the Administration of the State Border Guard Service of Ukraine, $40 \%$ - orders of heads of regional departments and divisions of the state border protection bodies (Fig. 2).

${ }^{8}$ Onishhenko N. M. (2008) Gharmonizacija pravovoji systemy Ukrajiny jak chynnyk zabezpechennja prav, svobod i zakonnykh interesiv ghromadjan [Harmonization of the legal system of Ukraine as a factor in ensuring the rights, freedoms and legitimate interests of citizens]. University research notes, vol. 4, no. 28, p. 20.

${ }^{9}$ Dubyna N. A., Taruta O. V. (2015) Problemy efektyvnosti zakonodavstva Ukrajiny [Problems of the effectiveness of Ukrainian legislation]. Law and security, vol. 2, no. 57, p. 25.

${ }^{10}$ Kindrat P. V. (2014) Efektyvnistj zakonodavstva: ponjatijno-terminologhichnyj aspekt [The effectiveness of Legislation: Conceptual and Terminological Aspect]. Legal Informatics, vol. 3 , no. 43 , p. 57.

${ }^{11}$ Shherba S. P., Shhedrin V. K., Zaghlada O. A. (2004) Filosofija [Philosophy]. Kyjiv: MAUP, p. 104 (in Ukrainian) 


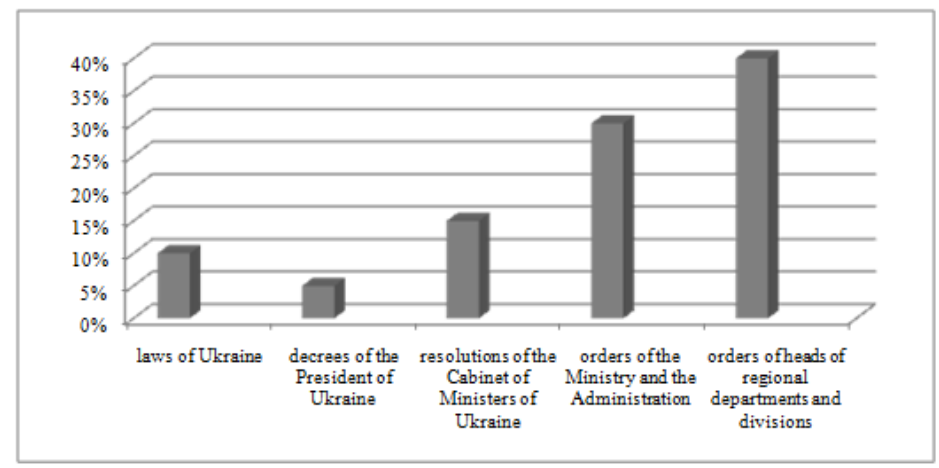

\section{Fig. 2. The quantitative indicator of normative acts that regulate activity of the State Border Guard Service of Ukraine}

Such a percentage ratio does not raise any particular questions and is logical for any branch of legislation, including legislation regulating the activity of the Border Service, where the norms of laws are detailed in subordinate normative acts, the specific gravity of which is significant, taking into account the need for detailed legal regulation of the specific functions of the State Border Guard Service of Ukraine to ensure the inviolability of the state border and the protection of Ukraine's sovereign rights in its exclusive (maritime) economic zone.

However, our detailed analysis of normative regulation of public relations at the state border shows its regulatory deficiency. In this case we can speak about mismatch of quantitative indicators with qualitative ones.

There are two scientific positions about the quality of normative acts. Representatives of the first speak about its correspondence to social needs. Thus, Natalia Onishhenko distinguishes two main aspects of the quality of legislation: social and legal.

Social manifests itself in accordance with the legal norms of the basic directions of development of society and correspondence to its real living conditions.

The legal aspect means that the normative acts must be lawful and include the principles of democracy and social justice.

The second position implies the mandatory presence of a set of features that make up the quality itself. In particular, Lyudmyla Legin names the following properties (attributes) of qualitative law: properties 
that characterize the law act as a form and source of law; properties that characterize the legal norm as the content of the law. In this case, the scientist talks about the form and content of the legal act, which must be accepted as the basis of a high quality legal act ${ }^{12}$.

In view of the above, under the quality of the legislation of the State Border Guard Service of Ukraine, we propose to consider the internal set of social and legal properties inherited its form and content, which determine the ability of normative acts to respond to the situation and new threats at the state border.

To date, the indicator of the quality of legislation in the field of border service activity needs to be refined. The most specific qualitative defects is shown on the figure 1(Fig. 1).

Many of the legal deficiencies, in our opinion, are caused by the lack of a clear and scientific-based recommendation, a general concept of development of legislation governing the activity of the Border Guard Service, which could clearly identify the vector of its further improvement, while ensuring its integrity, clear structure, mobility, stability and compliance with the state border situation. This conclusion is confirmed by the results of our poll, where $93 \%$ of respondents said they needed to create such a document ${ }^{13}$. Also, in the context of the aforementioned, I would like to cite the quite fair opinion of Oleksandr Yarmysh, who states that any transformations should have a systemic, scientifically based character ${ }^{14}$.

Working out the concept of legislation is a common practice today. Thus, while researching the problems of land legislation, Victoria Sydor proposed the Concept of its development ${ }^{15}$. At one time, the Concept of

${ }^{12}$ Leghin L. M. (2016) Ponjattja ta kryteriji jakosti zakonu: problemy vyznachennja [Concepts and criteria of quality of law: problems of definition]. Problems of legality: $a$ collection of scientific works, vol. 132, no. 16, pp. 196-204.

13 Basarab O. T. (2019) Zakonodavstvo, shho reghuljuje dijaljnistj Derzhavnoji prykordonnoji sluzhby Ukrajiny: formuvannja ta perspektyvy rozvytku [Legislation Regulating the Activity of the State Border Guard Service of Ukraine: Formation and Development Prospects] (PhD Thesis), Khmelnitskyi: Bohdan Khmelnitskyi National Academy of State Border Guard Service of Ukraine.

${ }^{14}$ Ghetjman A. (2013) Koncepcija rozvytku ekologhichnogho prava ta zakonodavstva jak peredumova zabezpechennja nacionaljnoji ekologhichnoji polityky [The concept of the development of environmental law and legislation as a prerequisite for ensuring national environmental policy]. Bulletin of the National Academy of Law of Ukraine, vol. 2, no. 1, pp. $165-173$.

${ }^{15}$ Sydor V. D. (2012) Teoretychni problemy rozvytku zemeljnogho zakonodavstva Ukrajiny [Theoretical problems of development of the land legislation of Ukraine] (Doctor of Law Thesis), Odessa: Odessa Law Academy. 
codification of the information legislation of Ukraine was presented by the authors of the Scientific Research Center of Legal Informatics with the Rights of the Research Institute of the National Academy of Law Sciences of Ukraine in the scientific journal "Information and Law"

It goes without saying that conceptual approach must be based on the compulsory combination of legal and specially applied knowledge of activity of the Border Guard Service, complex theoretical approaches to its further improvement, as well as recommendations for its optimization.

Taking into consideration the analysis of the modern legal framework on border protection and given means of its improvement by normmaking activity and systematization we worked out the Concept of development of the legislation of the State Border Guard Service of Ukraine as the way of improvement of its regulatory framework. The document consists of: general provisions; the main problems are planning to be solved; the ways of overcoming legislation problems; expected results of the Concept implementation.

The legal basis for the drafting of the Concept was the Constitution of Ukraine, laws and other acts of Ukraine in the border area, as well as international treaties. The purpose of the Concept is to create the basic legal and organizational grounds for the development and further improvement of the system of legislation in the sphere of the Border Guard Service activity in the context of its effective implementation at the state border.

The main problems that are planning to be solved with the help of the Concept are:

imperfection of norm-making activity, acts contain conflicts, gaps and inaccuracies;

lack of special terms in some spheres of Border Guard Service activity;

gaps in regulation of obligations of certain subjects of norm making activity in the sphere of Border Guard Service activity;

the level of scientific elaboration of the norm-making problem is not sufficient;

the regulatory framework on border issues has not been systematized earlier that is why it includes disorders;

${ }^{16}$ Koncepcija kodyfikaciji informacijnogho zakonodavstva Ukrajiny [The concept of codification of information legislation of Ukraine]. Informacija i pravo Information and law, vol. 1, no. 4. Retrieved from: http://ippi.org.ua/vid-redaktsiinoi-kolegii-rozrobka-proektukontseptsii-kodifikatsii-informatsiinogo-zakonodavstva-ukr. (accessed 31 October 2019). 
absence in each border unit an accessible electronic database of accounting of the current normative legal acts.

In the Conception it is proposed to overcome legislation problems in such ways:

planning and continuous monitoring of norm-making activity;

determination of areas that require priority regulation;

normative definition of powers of norm-making entities in the sphere of the State Border Guard Service of Ukraine activity;

working out orders and instructions on the procedure for creating legal acts on border issues, taking into account the specifics of secret documents;

conducting a large-scale audit of all regulatory material on border protection in order to identify regulatory deficiencies;

systematization of the regulatory framework of the State Border Guard Service of Ukraine;

introduction of proper accounting of legal acts and control over changes of legislation in order to maintain legal acts in a state of prompt receipt of the necessary legal information and readiness to apply norms.

Expected results of the Concept implementation are predicted as following:

regulatory framework of the State Border Guard Service of Ukraine will be improved;

normative accumulation will decrease;

an effective legal basis will be created for the management and control in the sphere of the State Border Guard Service of Ukraine activity;

the level of proper applying of acts during the border protection will increase, the number of errors in the process of implementation of legal norms will be reduced.

\section{CONCLUSIONS}

Taking into consideration results of the conducted research we can conclude that the legislation regulating activity of the State Border Guard Service of Ukraine can be accepted as the separate regulatory framework that is presented by the system of current material and procedural legal acts of Ukraine and the norms of international law, which determine the performance of the State Border Guard Service special functions in law enforcement, special, operational and combat forms of activity in order to ensure the inviolability of the state border and the protection of the sovereign rights of Ukraine in its exclusive (maritime) economic zone. 
Based on the doctrine of interpretation of the continental legal system the hierarchical structure of the legislation in the sphere of the State Border Guard Service activity consists of norms of international law, laws and subordinate legal acts (decrees and orders of the President of Ukraine; resolutions of the Cabinet of Ministers of Ukraine; directives and orders of the Ministry of Internal Affairs of Ukraine and the Administration of the State Border Guard Service of Ukraine; orders of normative character of regional departments and divisions of the State Border Guard Service of Ukraine).

Comprehensive researches of the current regulatory framework of the State Border Guard Service of Ukraine draw us to conclusion that it needs to be improved because of its regulatory deficiency (some of normative acts are obsolete, contain conflicts, inaccuracies, gaps in legal regulations, have declarative nature and insufficient promptness of amendments to legal documents in line with changes in the situation at the state border etc).

It is proved that many of the legal deficiencies are caused by the lack of a clear and scientific-based recommendation, a general concept of development of legislation governing the activity of the Border Guard Service, which could clearly identify the vector of its further improvement, while ensuring its integrity, clear structure, mobility, stability and compliance with the state border situation.

Totally, it can be assumed that today the legal framework on border protection needs quality conversion and the Concept of development of the legislation of the State Border Guard Service of Ukraine can definitely be considered as the way of its improvement.

\section{SUMMARY}

The article is devoted to the comprehensive study of the current state of the legislation in the sphere of the State Border Guard Service of Ukraine activity and the development of scientifically grounded proposals for its improvement. The Concept of development of the legislation of the State Border Guard Service of Ukraine was worked out.

The essence of the legislation regulating activity of the State Border Guard Service of Ukraine is proposed to understand as the system of current material and procedural legal acts of Ukraine and the norms of international law, which determine the performance of the State Border Guard Service special functions in law enforcement, special, operational and combat forms of activity in order to ensure the inviolability of the 
state border and the protection of the sovereign rights of Ukraine in its exclusive (maritime) economic zone.

The hierarchical structure of the legislation of the State Border Guard Service of Ukraine depends on the legal force of normative acts. It is consists of the norms of international law, laws and subordinate legal acts.

Taking into consideration the analysis of the modern legal framework on border protection and given means of its improvement by normmaking activity and systematization it is proposed to work out the Concept of development of the legislation of the State Border Guard Service of Ukraine. The content of the document consists of: general provisions, which define the legal basis, the purpose of the Concept, the main problems that are planning to be solved, the ways of overcoming legislation problems and expected results of the Concept implementation. The presented proposals in the research are directed to the development of the legislation of the State Border Guard Service of Ukraine in order to improve the quality of its implementation during the border protection.

\section{REFERENCES}

1. Alexander Turk. (2006) The Concept of Legislation in European Community Law: A Comparative Perspective. New York: Kluwer Law International B.V.

2. Cambridge Dictionary Cambridge: Cambridge University Press University Printing House. Retrieved from: https://dictionary.camb ridge.org/dictionary/english/legislation (accessed 16 October 2019).

3. Sukhodubova I. V. (2015) Ekonomichna teorija ta pravo [Economic theory and Law]. Law and security, vol. 1, no. 20, p. 272-273.

4. Konstytucija Ukrajiny vid 28 chervnja 1996 roku No. 254k/96VR. [Constitution of Ukraine of June 281996 No. 254k / 96-VR.]. Retrieved from: http://zakon3.rada.gov.ua/laws/show/254\%D0\%BA/960\%B2\%D1\%80 (accessed 16 October 2019).

5. Pro Derzhavnu prykordonnu sluzhbu Ukrajiny : Zakon Ukrajiny vid 3 kvitnja 2003 roku No. 661-IV [On the State Border Service of Ukraine: Law of Ukraine of 3 April 2003 No. 661-IV]. Retrieved from: http://zakon2.rada.gov.ua/laws/show/661-15/page (accessed 31 October 2019).

6. Pro perelik osnovnykh kerivnykh dokumentiv : Nakaz Administraciji Derzhavnoji prykordonnoji sluzhby Ukrajiny vid 16 bereznja 2015 roku No. 63 [On the List of Basic Guidance Documents: Order of the Agency of the State Border Guard Service of Ukraine dated 
March 16, 2015 No. 63]. Retrieved from: https://dpsu.gov.ua/ (accessed 31 October 2019).

7. Rabinovych P. M. (2007) Osnovy zaghaljnoji teoriji prava ta derzhavy [Fundamentals of the general theory of law and state]. Lviv: Kraj. (in Ukrainian)

8. Onishhenko N. M. (2008) Gharmonizacija pravovoji systemy Ukrajiny jak chynnyk zabezpechennja prav, svobod i zakonnykh interesiv ghromadjan [Harmonization of the legal system of Ukraine as a factor in ensuring the rights, freedoms and legitimate interests of citizens]. University research notes, vol. 4, no. 28, p. 20.

9. Dubyna N. A., Taruta O. V. (2015) Problemy efektyvnosti zakonodavstva Ukrajiny [Problems of the effectiveness of Ukrainian legislation]. Law and security, vol. 2, no. 57, p. 25.

10. Kindrat P. V. (2014) Efektyvnistj zakonodavstva: ponjatijnoterminologhichnyj aspekt [The effectiveness of Legislation: Conceptual and Terminological Aspect]. Legal Informatics, vol. 3, no. 43, p. 57.

11. Shherba S. P., Shhedrin V. K., Zaghlada O. A. (2004) Filosofija [Philosophy]. Kyjiv: MAUP. (in Ukrainian)

12. Leghin L. M. (2016) Ponjattja ta kryteriji jakosti zakonu: problemy vyznachennja [Concepts and criteria of quality of law: problems of definition]. Problems of legality: a collection of scientific works, vol. 132, no. 16, pp. 196-204.

13. Basarab O. T. (2019) Zakonodavstvo, shho reghuljuje dijaljnistj Derzhavnoji prykordonnoji sluzhby Ukrajiny: formuvannja ta perspektyvy rozvytku [Legislation Regulating the Activity of the State Border Guard Service of Ukraine: Formation and Development Prospects] (PhD Thesis), Khmelnitskyi: Bohdan Khmelnitskyi National Academy of State Border Guard Service of Ukraine.

14. Ghetjman A. (2013) Koncepcija rozvytku ekologhichnogho prava ta zakonodavstva jak peredumova zabezpechennja nacionaljnoji ekologhichnoji polityky [The concept of the development of environmental law and legislation as a prerequisite for ensuring national environmental policy]. Bulletin of the National Academy of Law of Ukraine, vol. 2, no. 1, pp. 165-173.

15. Sydor V. D. (2012) Teoretychni problemy rozvytku zemeljnogho zakonodavstva Ukrajiny [Theoretical problems of development of the land legislation of Ukraine] (Doctor of Law Thesis), Odessa: Odessa Law Academy.

16. Koncepcija kodyfikaciji informacijnogho zakonodavstva Ukrajiny [The concept of codification of information legislation of Ukraine]. 
Informacija i pravo Information and law, vol. 1, no. 4. Retrieved from: http://ippi.org.ua/vid-redaktsiinoi-kolegii-rozrobka-proektu-kontseptsiikodifikatsii-informatsiinogo-zakonodavstva-ukr. (accessed 31 October 2019).

\section{Information about the author:}

Olha Basarab,

Candidate of Law Sciences ( $\mathrm{Ph} \mathrm{D})$,

Senior lecturer of the History and Theory of the State and Law and Private Law disciplines department,

Bohdan Khmelnytskyi National Academy of the State Border Guard Service of Ukraine 46 Shevchenko str., Khmelnytskyi, Ukraine ORCID ID: orcid.org/0000-0001-7839-6955 